THE LONDON SCHOOL

OF ECONOMICS AND

POLITICAL SCIENCE

No: $210 / 2014$

\title{
Sailing Away from Malthus: Intercontinental Trade and European Economic Growth, 1500-1800
}

\author{
Nuno Palma \\ London School of Economics \\ School of Business and Management, \\ Queen Mary, University of London
}




\title{
LONDON SCHOOL OF ECONOMICS AND POLITICAL SCIENCE \\ DEPARTMENT OF ECONOMIC HISTORY \\ WORKING PAPERS \\ NO. 210- SEPTEMBER 2014
}

\section{Sailing Away from Malthus: Intercontinental Trade and European Economic Growth, 1500-1800}

\author{
Nuno Palma \\ London School of Economics \\ School of Business and Management, Queen Mary, University of London \\ n.p.palma@1se.ac.uk
}

\begin{abstract}
What was the contribution of intercontinental trade to the development of the European early modern economies? Previous attempts to answer this question have focused on static measures of the weight of trade in the aggregate economy at a given point in time, or on the comparison of the income of specific imperial nations just before and after the loss of their overseas empire. These static accounting approaches are inappropriate if dynamic and spillover effects are at work, as seems likely. In this paper I use a panel dataset of ten countries in a dynamic model which allows for spillover effects, multiple channels of causality, persistence and country-specific fixed effects. Using this dynamic model, simulations suggest that in the counterfactual absence of intercontinental trade, rates of early modern economic growth and urbanization would have been moderately to substantially lower. For the four main long-distance traders, by 1800 the real wage was, depending on the country, 6.1 to $22.7 \%$ higher, and urbanization was 4.0 to 11.7 percentage points higher, than they would have otherwise been. For some countries, the effect was quite pronounced: in the Netherlands between 1600 and 1750, for instance, intercontinental trade was responsible for most of the observed increase in real wages and for a large share of the observed increase in urbanization. At the same time, countries which did not engage in long-distance trade would have had real wage increases in the order of 5.4 to $17.8 \%$ and urbanization increases of 2.2 to 3.2 percentage points, should they have done so at the same level as the four main traders. Intercontinental trade appears to have played an important role for all nations which engaged in it, with the exception of France. These conclusions stand in contrast with the earlier literature which uses a partial equilibrium and static accounting approach.
\end{abstract}

\section{Keywords: Early Modern Economic Growth, Economics of Empires}

$$
\text { JEL Codes: N10, N13, N70, N74, O47, O57 }
$$

Acknowledgements: I am grateful to Leonor F. Costa, Maxine Montaigne, Chris Minns, Rui Pedro Esteves, Jaime Reis, and especially Leandro Prados de la Escosura, for comments or discussions. The usual disclaimer applies. 


\section{Introduction}

How important was intercontinental trade for the development of the European economies? This is a classic question in economic history, and one for which no consensus has been reached. The World-systems theory and the "dependency-theory" historiographical traditions argue that longdistance trade mattered a lot because it allowed Europeans to accumulate large amounts of capital which jump-started its process of development (Marx 1990/1867, Wallerstein 1974, 1980, Frank 1978, Williams 1994/1944). ${ }^{2}$

By contrast, a revisionist literature considers that long-distance trade contributed only modestly at best, since, it argues, the external sector constituted a relatively small share of the early modern economies, and the quantities of capital accumulated as a direct consequence of trade were by no means sufficient to justify Europe's advantage (O’Brien 1982, Mokyr 1985). It was further shown, using specific case studies, that the loss of empires had only trivial consequences for the European colonizers (O’Brien and Engerman 1991, O’Brien and Prados de la Escosura 1998).

The revisionist literature made a useful contribution in the context of its time, as the importance of international trade had been clearly exaggerated by earlier neo-Marxist literature. But the revisionist literature is always based on a series of static comparisons, for instance relying on the Smith-Myint notion of "vent for surplus" (Myint 1977). However, as Findlay and O'Rourke (2007, p. 337) write, "comparative static models cannot, by definition, say anything about the impact of trade on growth". The reason for this shift in thinking is that there may be indirect, dynamic general equilibrium, and spillover effect gains from trading. For instance, suppose an urban trade boom raises wages and then induces rapid development of labor-saving technological change. This growth-enhancing effect is completely absent from static calculations, which would incorrectly conclude that without trade, all else would be constant: GDP would only decrease by the amount of that trade.

Another possibility is that long-distance trade may have indirectly promoted good institutions through a political economy effect: trade mattered indirectly, because of the additional wealth, and by consequence political power, that it brought to the merchant class (Braudel 1980, Acemoglu, Johnson and Robinson 2005). Once again the key word here is "indirectly"; if indeed distributional issues in association with political economy were present, then a static calculation which simply wipes out trade and assumes all else is constant would completely miss out on this effect. Another likely channel is that of Romer (1993), which suggests that the transmission of new ideas may be an unsung source of gains from trade, a concept which seems to fit well with the narrative evidence for the early modern period.

Did the revisionist literature go too far? Towards an answer, I estimate a dynamic model of the early modern European economy (following, but also improving, on Allen 2003, 2009). This is a dynamic model which takes into consideration a wealth of causal factors, in particular allowing for the endogeneity of urbanization and the real wage (among other variables). Additionally, it allows for macroeconomic persistence and (implicitly) general equilibrium effects. I estimate this model using Allen's (updated) dataset, complemented with data for Portugal from Costa, Palma and Reis (2014). In order to control for the possibility of country-specific factors, such as "culture" or the way the empires were run (e.g. crown-sponsored empires vs. merchant companies), affecting the

${ }^{2}$ See also Pomeranz (2000). 
results I go a step beyond Allen and use more advanced estimation techniques which allow controlling for (time invariant) fixed effects (Arellano 2004). It is then possible to simulate alternative histories which allow for a new assessment of the dynamic economic growth and urbanization effects of intercontinental trade.

I find that engaging in overseas trade allowed the mother economies in Europe to maintain real wages at levels which would not have been otherwise possible, and hence contributed to an early escape from a "Malthusian" stagnation steady state. Thanks to effects of intercontinental trade and to a lesser extent, migration overseas, which created some slack in the land-labor ratios - by 1800 , the real wage was 6.2 (Spain) to 22.7 (Portugal) per cent higher in the main four longdistance trade nations, while urbanization was 3.9 (Spain) to 11.7 (England) percentage points higher, than it would have been without that trade. ${ }^{3}$ At the same time, countries which did not engage in long-distance trade would have had real wages increases in the order of 5.4 (Italy) to $17.8 \%$ (Germany) and urbanization increases of 2.2 (Germany) to 3.2 (Poland) percentage points by 1800 , should they have had done so at the mean level of the four main long-distance traders. I hence complement the work of Allen (2009) for England, and that of Costa, Palma and Reis (2014) for Portugal, by showing detailed results on the counterfactual effect of shutting off intercontinental trade on the economic growth and urbanization rates of the additional eight European countries for which the data required for the exercise is available. ${ }^{4}$

\section{How should the contribution of intercontinental trade be measured?}

In the debate over the causes of the industrial revolution, at least from the late 1970's to the early 2000's the dominant view in economic history was that the British Industrial Revolution had been a consequence of internal factors, and hence trade (or government policy) did not matter much. This position, most prominent in Thomas and McCloskey (1981), is summarized in Mokyr (1985, p.23), who after reviewing a series of static comparisons concludes that "the assertion that the British Empire was an important element in the Industrial Revolution is by now discredited".

And yet, as of late the pendulum has been swinging the other way. In sharp contrast with the revisionist position, but perhaps more in line with the traditional view of many historians, Findlay and O'Rourke (2007, p. 339) write that international trade was a key reason why the British Industrial Revolution was sustained and that "the success of the European Industrial Revolution is intimately connected with trade and overseas expansion" (p.364). In what may be interpreted as a sign of the times, Patrick O'Brien has changed his mind on the importance of the external sector (see for instance, O’Brien 2006), and even Joel Mokyr, while insisting other factors were more important, now presents a much more nuanced position (Mokyr 2009, p. 25-6, 145-6, 155-162).

The motive underlying this shift is a sharper understanding of the critical need to use dynamic models in assessing outcomes under a no-trade counterfactual. While the revisionist literature is more historically cautious, quantitatively inclined and better informed in economic terms, it faces difficult identification problems. For instance, one approach is to compare the social rate of return from the investments made by the home country externally with the yield obtainable in the mother economy with the same stock of capital and controlling for the appropriate risk premium

\footnotetext{
${ }^{3}$ Notice the difference in units: it is more convenient to express effects on urbanization in percentage point increases, since the original unit is itself already a percentage.

${ }^{4}$ I have used the most recent data available for the simulations in this paper. There are some small differences in the results relative to those reported in those papers due to the updating of the data.
} 
(Thomas 1968). This approach has an important limitation: it implicitly assumes that if all of the capital which was invested in externally had been instead invested internally, the (marginal) rate of return for the latter would not have been different. In other words, it makes a "small economy" assumption on the rate of return, taken to be a constant. It is hard to believe this is credible, since it is likely that in equilibrium the rate would have been lower, as marginal investments at home would have only been available at diminishing returns, due to the existence of fixed factors complementary to capital, such as land, labor, or entrepreneurial capital. We can then see that assuming a fixed rate of return biases Thomas's result against finding a large effect, since it appears as if the "opportunity cost" rate of return at home was higher than it in fact would have been under equilibrium.

For the imperial economies, a related literature has attempted to recover the "empire effect" by comparing the national output of these economies before and after the loss of empire. For instance in the case of Spain, these static accounting methods lead to the conclusion that the loss of the greater part of the empire in the early nineteenth century led to a fall of between 3.0 to 8.4 per cent of GDP (Prados de la Escosura 1988, 1993). For Portugal, the equivalent number ranges from 3.4 to 8.0 per cent (Pedreira 1994). Similar magnitudes were found for Britain (Thomas and McCloskey 1981). Hence the conclusion has been, for all cases, that the loss of the empires did not matter much - and more generally, empire itself had probably never mattered that much.

However, the loss of the empires is not a valid natural experiment. If colonial independence and, by implication, the substantial loss of colonial networks and property was at least in part anticipated by the entrepreneurs in Europe, then fewer investments will have been made in the last few years of the empire, invalidating the exercise. More generally, a static comparison of loss of GDP associated with the loss of the colonies is inappropriate if dynamic general equilibrium, macroeconomic persistence, and spillover effects are at work, as seems likely. The biggest opportunity cost from losing an empire was not likely to have been the one-time fall in GDP associated with the loss, but instead the lower rates of growth and structural change which resulted - especially outside of a political "free trade" context.

The revisionist literature's main points that the previous emphasis on capital accumulation as stressed by the Neo-Marxist literature was exaggerated, and that the capital gains from longdistance trade alone cannot explain Europe's economic performance over the long run, are likely to survive the test of time. ${ }^{5}$ At the same time, the identification problems discussed above suggest that the true importance of intercontinental trade in explaining the long term development of the European economies is still an open question.

In fact, the counterfactual of "what would happen to a given economy without intercontinental trade" does not correspond to simply wiping out that trade while assuming all else would be constant. The answer provided by a ceteris paribus comparative statics exercise is not of primary interest to economic historians. Instead only a model which considers a dynamic equilibrium and allows for persistence as well as spillover effects can adequately model the effect of trade on growth. While no consensus has emerged over which model should be used to evaluate this effect,

\footnotetext{
${ }_{5}^{5}$ To this I would add that the dependency theorists' emphasis on the critical importance of capital accumulation is also difficult to square with the discovery of Solow (1957) that TFP change, not capital accumulation, is the main driver of economic growth - though of course, Solow's data, as that of most of the growth accounting literature, refers to modern economies. See, however, Bond, Leblebicioglu and Schiantarelli (2010).
} 
Allen's (2003, 2009) model seems appropriate since it allows for macroeconomic persistence and, implicitly, spillover and general equilibrium effects.

\section{The model and estimation strategy}

Allen's (2003, 2009) model can be used (and improved on) by following three steps. First, one defines the variables to be used and the identification assumptions which define the relationships between them, including which of these are to be considered endogenous, and which are to be treated as instrumental variables (IV's). The usage of these sources of exogenous variation in the (otherwise) endogenous variable allows one to recover the effect of, for example, an increase in urbanization on the real wage. (It must be said at the outset that treating intercontinental trade as exogenous is a key maintained hypothesis here, as are the remaining exclusion restrictions which make up the Allen's model.) Second, the parameters are estimated using the data, and alternative estimation methods can be considered. Finally, one takes the preferred choice of (point) estimated parameters, and solves the system so that simulations can be performed. Each of these steps shall be detailed in the following discussion.

The underlying data is taken from Allen's revised dataset and (in the case of Portugal) from Costa, Palma and Reis (2014). The amounts of per capita intercontinental trade are shown (in real terms) in figure 1. Then the impact of several covariates on four endogenous variables is estimated each period. The (skilled) real wage, the urbanization rate, the agricultural total factor productivity (TFP) and the share the proto-industrial labor share serve as the model's endogenous variables, while the land-labor ratio, manufacturing TFP, share of land under enclosure, intercontinental trade and lagged urbanization are taken as exogenous. Ideally, using GDP per capita would be better than using the real wage, but due to lack of data availability for four of the countries in the sample, doing so would severely reduce the sample size and the power of the statistical tests. However, Costa, Palma and Reis (2014) show that for the countries for which GDP per capita is available, it is strongly correlated with the real wage, a relationship which is also significant at the standard levels. This result suggests using the real wage is an appropriate proxy. ${ }^{6}$

\section{FIGURE 1}

The model is estimated using a sample of ten European countries, each of which is observed at five benchmark periods: 1500, 1600, 1700, 1750 and 1800. The choice of countries and years has been based solely on data availability for the variables needed. ${ }^{7}$ The countries - defined under the "modern borders" of 1945 convention - are the nine countries in Allen's original sample (England and Wales, the Netherlands, Italy, Germany, Poland, Austria/Hungary/Czechoslovakia, Spain, France, Belgium; Allen 2003, p. 405) plus Portugal. In the model, lagged urbanization serves as the "state variable": it records all that needs to be known about the past at the beginning of each new period. Hence, persistence is allowed for since the same contemporaneous controls lead to

\footnotetext{
${ }^{6}$ By using the real wage instead of GDP per capita, I am also biasing the results against finding an economically and statistically significant effect of intercontinental trade on GDP for two reasons: First, distributional issues suggest that if many of the gains from trade stayed concentrated in the hands of the merchant class, then the real wage index will be missing those effects; second, since the nominal wage underlying the construction of the real wage index is the day wage, if people worked more days stimulated by trade - as suggested by deVries (2008) and Hersh and Voth (2010) - then it will have been the case that the full effect of trade on GDP per capita will have been underestimated by using the real wage as a proxy.

${ }^{7}$ For instance, Denmark and Sweden did also engage in intercontinental trade as well but the required data for these countries is not available.
} 
different combined effects on the dependent variables depending on how the economy evolved in the past. The model is linear by assumption and further identified by several exclusion restrictions which apply to the endogenous variables.

The exclusion restrictions are as follows. First, the wage is assumed not to affect (directly) protoindustry or urbanization, and proto-industry is assumed to only affect directly agricultural productivity. Second, urbanization is allowed to directly affect both the real wage and agricultural TFP, but not the proto-industrial labor share. Third, agricultural TFP can directly affect all three other endogenous variables. (Notice that indirectly, all variables are able to affect each other in the future via the current urbanization level, which will serve as a state variable in the next period.) Finally, the percentage of land under enclosure, the lag of the urbanization ratio, the level of intercontinental trade per capita (in constant prices of 1700), a dummy for the Spanish empire, a dummy for the British empire, the manufacturing sector TFP, and the price of energy and are used as instruments for the endogenous variables (the results are not sensitive to the most alternative choice of instruments defined by excluding some of the above.)

I now show the results for two of the four endogenous variables. ${ }^{8}$ Table 1 focuses on the real wage. In column (1), it includes OLS estimates, which have only a statistical interpretation, but nonetheless show partial correlations which are of interest for comparative purposes. Column (2) replicates Allen's 2SLS estimates. In column (3) I use a more modern estimation method which is appropriate for the data and problem at hand, the dynamic-panel Arellano-Bond estimator. This is a consistent GMM estimator for 'short' panels, which allows for unobserved panel-level effects potentially correlated with lagged dependent variables. (It allows for idiosyncratic heteroskedastic errors which are correlated within countries, but not across countries. $)^{9}$

\section{TABLE 1}

Inspection of the results shows that the various estimated coefficients do not change much when alternative methods are used. ${ }^{10}$ The same is true for the urbanization equation estimates (table 2), and for the estimates for the other two variables taken to be endogenous (results not shown).

\section{TABLE 2}

The variables used for the estimation of the model are in natural logs, hence the coefficients can be interpreted as elasticities. (The only exception is the institutions dummy, which corresponds to a discrete effect.) For the present purpose the most relevant results are the point estimates which

\footnotetext{
${ }^{8}$ I focus on reporting and interpreting the results for the real wage and on the urbanization rate. The results for the other two endogenous variables, the share of labor in proto-industry and the agricultural total factor productivity, are available upon request.

9 The point of using this estimator is as follows. Since unobserved country-specific idiosyncrasies in the error term (eg. the micro details about how the empires or merchant networks of different countries were run) could be leading the pooled estimation methods to inconsistent parameter estimates, it may be possible to improve on the precision and credibility of the estimates by taking advantage of the panel data structure of the data. However, because lagged urbanization appears as an independent variable in some of the equations, the standard fixed effects estimator should not be used (Nickell 1981). One possibility would be to drop this variable, but since persistence plays a key role in the story, it is important to keep it. This problem can be solved using a dynamic panel-data estimator: this way we can allow for both persistence and (time-invariant) country-specific fixed effects.

${ }^{10}$ I also include an "IV robust F-statistic" row in each of the regression tables, and this shows the instruments are not weak, even under the most modern criteria (Stock and Yogo 2005).
} 
indicate that a $10 \%$ increase in the land-labour ratio leads to a $4.4 \%$ increase in the real wage, and the same percentage increase in the urbanization rate leads to a $2.5 \%$ increase in the real wage. As for the second table, we can see that a $10 \%$ increase in intercontinental trade leads to a $1.2 \%$ increase in urbanization, and that a $10 \%$ increase in past urbanization leads to a $7.7 \%$ increase in current urbanization. (All of these results are statistically significant at the $10 \%$ or lower levels.)

\section{The effect of intercontinental trade on European economic growth and urbanization}

I am now at a position to simulate the impact of intercontinental trade on the dynamic evolution of these economies. To simulate the real wage and urbanization rate I solve the system, employing the estimated parameters and feeding in the historical data for the different explanatory variables. I then repeat the same procedure, but now imposing zero intercontinental trade. The difference between the two outcomes is the model's simulated response to the impact on the home country's economy of having engaged in intercontinental trade. Notice it is not a "static" or an "all else constant" answer, since the model's endogenous variables are allowed to respond to changes in trade, both now and in the future (through the effect of lagged urbanization).

Following this procedure it is hence possible to predict a (non-deterministic) path for the historical real wage and urbanization levels (as well as the other two endogenous variables), and these paths can be compared with the prediction for what would have happened under a counterfactual "no imperial trade" situation. Allen (2009, p. 125-6) does this for the well-known English case, a result I reproduce in figure 2.

\section{FIGURE 2}

Using this model it is possible to simulate the dynamic evolution of the real wage and urbanization rates for other early modern imperial economies as well (figures 3 and 4 ). ${ }^{11}$ It stands out that for four out of five of these economies, intercontinental trade played an important role in maintaining a high level of the real wage (largely by generating gains which arrested the tendency for decline which would have otherwise existed due to Malthusian population pressure), as well as increasing urbanization. These effects are small in the case of France, moderate in the case of Spain, and particularly large for England, the Netherlands, and Portugal.

\section{FIGURE 3}

\section{FIGURE 4}

The cases of England and Portugal have been discussed extensively in, respectively, Allen (2009) and Costa, Palma, and Reis (2014), hence here I focus on the remaining cases - including the

\footnotetext{
${ }^{11}$ Allen's model of the early modern economy is not without disadvantages. The exclusion restrictions which identify the model, and hence make it estimable, are taken as maintained assumptions, which is unavoidable. (I did not perform tests of over-identifying restrictions, since the current consensus among econometric theorists is that these tests cannot be used to test for instrument validity; see for instance, Parente and Silva 2012.) A different criticism could be that even after controlling for the series of variables included, there may be something unobservable about some of the particular countries which would be driving the results. However, I also consider a number of robustness adjustments and alternative estimation methods, in particular, those specifically designed for panel data and which account for fixed-effects. Further, I address the possibility of - potentially time-variant - "unobservable" idiosyncratic effects in detail in the appendix. In any case, the safest way to think about the results is that they are conditional on Allen's model for the European early modern economy, the key assumptions of which are maintained throughout the analysis.
} 
estimated counterfactual effects for those which did not engage in oceanic trade at all, such as Poland. In the case of the Netherlands, it is noteworthy that these simulations suggest that much of the real wage and urbanization gains during the "golden age" (here, 1600-1750) were attributable to intercontinental trade. In this period, the real wage became $7.4 \%$ higher than it would have otherwise been, and urbanization 7.4 percentage points higher. (Notice the change in units: urbanization effects are measured in percentage points, not percent.)

Even in the case of Spain, where, due to relatively small amounts of per capita intercontinental trade, the effects were not as large as elsewhere, they were nonetheless non-negligible: a real wage of about 7.5 instead of 7 in 1800, and growing levels of urbanization (instead of declining, under the no-trade scenario). ${ }^{12}$ The only exception of a country for which no important effects may be said to have been attributable to intercontinental trade was France, an unsurprising outcome in light of the fact that, as shown in figure 1, France had a very little intercontinental trade in per capita terms. In table 3, I show the proportion in which real wages grew, at different points in time, as a consequence of engaging in intercontinental trade. Further, in parenthesis, I show the percentage point effect on urbanization.

\section{TABLE 3 HERE}

It is possible to follow up on this line of thought by considering a further series of counterfactual experiments for the countries which did not engage in intercontinental trade (table 4). The simulations suggest, for instance, that if Poland had access to a per capita level of trade similar to that of the average of the four main European long-distance trading nations (i.e. France excluded), then it would have arrested about half of its observed decline in real wages - its real wage would have been, by $1800,12.1 \%$ higher than was the case, and its urbanization 3.4 percentage points higher. ${ }^{13}$

\section{TABLE 4 HERE}

The real wage effects are particularly large for Poland, but are nonetheless far from negligible for the others. Had Italy, Germany, or Austria/Hungary/Czechoslovakia engaged in intercontinental trade at the average level of the four main "Atlantic traders", they would have realized real wage gains from 5.4 (Italy) to 7.7\% (Austria) and an urbanization bonus of 2.2 (Germany) to 3.1. (Italy) percentage points. Of course, whether it would have been feasible for these countries to engage in these volumes of intercontinental trade in direct competition with the long-distance trading nations that did is a relevant question. But the goal here is not to actually suggest that for these countries engaging in intercontinental trade would have been a historically realistic possibility: as always, historical extrapolations need to be handled with great care. Instead, the point is that this exercise may give us some perspective on what the likely contribution of long-distance trade for the nations that did engage in it may have been. ${ }^{14}$

\footnotetext{
${ }^{12}$ Notice, then, that it seems the estimates of Prados de la Escosura $(1988,1993)$ for Spain have turned out to be closer to the mark than those of Lains (1991) or Pedreira (1994) for Portugal, as well as those of Thomas and McCloskey (1981) for Britain.

${ }^{13}$ Further results (not shown) suggest that if instead it had access to per capita levels of trade equivalent to those of Portugal, it would have arrested most of its decline, and in fact it would have even growth a little from 1700 onwards.

${ }^{14}$ I do not include Belgium in the table due to this country's unusually large residual: the model's prediction for the historical case (which we can compare with the data), is somewhat worse than for the other countries; see the appendix for further details and a formal justification. I emphasize that by doing so I am biasing the results against the thesis that intercontinental trade mattered, as the simulated effect for Belgium is even larger than that of Poland.
} 


\section{Sailing away from Malthus}

It is possible to attain better intuition of the importance of intercontinental trade for each country by considering its effects side by side with those of observed increases in population. For each economy, increases in population - and hence decreases of the land-labor ratio - meant, with all else constant, diminishing returns to agricultural production and lower levels of income. The early modern expansion of the population is the most likely culprit for the observed overall decline in real wages.

Keeping this in mind, I now consider a series of experiments designed to evaluate the contribution of intercontinental trade in arresting the decline in real wages and in promoting increases in urbanization, when compared with the simulated gains from keeping population (counterfactually) constant after 1600. The choice of this date is arbitrary and simply based on the observation that under the five possible choices of a benchmark, 1500 would have been "too early" to consider this experiment since most countries did not have non-negligible levels of trade then. (Further, as is well-known European population levels had not yet fully recovered from the shock of the Black Death and subsequent plagues.) At the same time, 1700 is too late to consider this exercise, so 1600 seems on the whole the appropriate choice.

I start with the effect on the real wage (figure 5), and then proceed to the urbanization rate (figure 6)..$^{15}$ For each country the solid line shows the simulated historical path, as in figures 2 and 3. Then the broken line in which benchmarks are marked with a triangle marker shows the predicted path with population constant after 1600. As expected, the result is that for all the countries the real wage shoots up after that date, and the magnitude of the effects on urbanization is large as well.

\section{FIGURE 5}

\section{FIGURE 6}

But the most important comparative insight can be achieved - in addition to keeping population constant after 1600 - by also shutting off intercontinental trade (the result is shown under the broken line with round markers). Now the previous results gain some comparative perspective. For some countries such as Portugal in 1700 and even Spain as late as 1750, the returns from the empire led to gains in the real wage which were equivalent or even above those of keeping population henceforth always constant at the 1600 level. Hence for these countries, the overseas empires generated returns for the mother economies which cancelled much of the tendency towards decline in real wages which would have naturally occurred as a result of population expansion, maintaining wages at relatively high levels which would not have been possible without a (historically unlikely) negative demographic response, and sometimes even generating per capita economic growth. ${ }^{16}$ In addition, colonies and merchant companies allowed for migration

\footnotetext{
${ }_{15}$ Two notes about figures 5 and 6 are in order. First, I do not show France since as discussed before its low level of per capita trade could only trivially lead to small effects. Instead, I show England in these graphs. Second, the scale in the vertical axis for the Netherlands in figure 6 and for England in both figures is extended.

${ }^{16}$ Further results (not shown) suggest that for the countries which did not engage in intercontinental trade, having done so at the average level of the "big four" would have been able to cancel much of the real wage losses associated with their own post-1600 population growth.
} 
opportunities to different lands. These population outflows created some slack in the land-labor ratios of the countries for which trade opportunities were available, further allowing for a persistent deviation from convergence to a Malthusian stagnation steady state.

\section{Conclusion}

Faced with Malthusian pressure, economies look for ways out. For a given initial combination of preferences, technology, endowments, and institutions, an escape may or may not be available. But it must be recognized that, unlike what may be suggested by the real wage data of Allen (2001) or Clark (2005) - and in particular, in contrast with what has been forcefully claimed by Clark (2007) - many early modern European economies did experience extended periods of intensive growth. ${ }^{17}$

Indeed, while the long-term behaviour of the skilled real wage may suggest, for most countries, either stagnation or - depending on how early one starts the analysis - even decline, one must remember that this is an imperfect measure of growth. ${ }^{18}$ Indeed, several factors which were behind early modern intercontinental trade-driven economic growth will be missed if one looks at the real wage only. First, distribution effects may have been important: perhaps merchant groups captured the bulk of the gains, and this did not fully trickle down. Second, any capital gains will be missed. Third, effects on productivity change will be missed.

Finally, there is the important possibility of an increase in the number of working hours, and in particular, working days. The nominal wage underlying the construction of real wage data is the day wage. Hence the real wage data of Allen (2001, 2003) and Clark (2007), which is based on a maintained assumption of a fixed number of days (250 in the case of Allen), will almost surely underestimate actual growth, since the new consensus is that Europe underwent an "industrious revolution" of an increase in the number of working days per year (Voth 2001, de Vries 2008) and it has been now further shown that this increase was not restricted to Northwestern Europe (e.g. Álvarez-Nogal and Prados de la Escosura 2013, Palma and Reis 2014). For this reason, all of these economies grew in intensive (as well as extensive) terms.

For those economies, income growth was simply faster than the demographic response. For sure, the premodern economies that did grow did so at rates which were slower than those of modern economic growth and the sources of growth tended to be more Smithian (due to increased specialization and market integration) than Schumpeterian (technical change) in nature but always included some of the latter as well. ${ }^{19}$ Clearly, the existence of some intensive growth was not a sufficient condition for a definite take-off. But the fact that much of early modern Europe was taking the period as whole - one such case, is an important background to understanding the timing and location of the emergence of modern economic growth.

\footnotetext{
17 Despite stagnated or declining real wages, during the early modern period there was per capita GDP growth in Britain (Broadberry et al 2011), Holland (van Zanden and van Leeuwen 2012), and Portugal (Palma and Reis 2014), though usually the growth was not consistent; for Spain the evidence is more mixed (Álvarez-Nogal and Prados de la Escosura 2013), and in the case of North and Central Italy most of the period is one of decline (Malanima 2011).

${ }^{18}$ For a convenient summary of the differences and a variance decomposition exercise for the case of England, see Angeles (2008).

19 One classic case is Sung China (Jones 1988), and usually the intensive growth was also accompanied by population growth and hence some extensive growth as well (Goldstone 2002), but the fact remains that income per person, and not just population density, increased during long periods of time.
} 
What is certain is that the European regions which engaged in larger amounts of intercontinental trade tended to either grow more or declined less, especially in relative terms when compared with what the overall European trend was at a given period. Although based on this fact alone - and even after "controlling" for several covariates - it is difficult to attribute straightforwardly any direction of causation, the most historically plausible scenario seems to be that during the early modern period the nations which were able to explore their technological, geographic and institutional conditions in order to build and maintain empires or other long-distance merchant networks benefited a great deal from them: not due to the direct effect of capital accumulation, but to the technological, organizational, and institutional spillovers that this trade generated. ${ }^{20}$

Indeed, for the early modern imperial European economies, intercontinental trade organized along mercantilist strategic orientations was a key opportunity. It provided access to new and exciting goods from Asia and America which were under inelastic supply in Europe, and promoted the development of national manufacturing industries. Spillover effects resulting from intercontinental trade led to changes in urbanization and regional specialization, but they cannot be measured by static accounting methods (Findlay and O'Rourke 2007). ${ }^{21}$ I have suggested an alternative way to measure them, using a dynamic model which allows for macroeconomic persistence and indirect, general equilibrium effects.

The resulting simulations which result from a series of no-trade counterfactual exercises suggest that the early modern European imperial economies would have experienced a drop in incomes in the absence of intercontinental trade. The existence of these empires meant that unlike other parts of Europe they at the very least able to sustain comparatively high levels of wages, when contrasted in the Asian mirror (Broadberry and Gupta 2006). The quantification presented here is certainly not the only one possible, and because it is not built on specific "microfoundations" it needs to be interpreted as reduced form evidence. At the same time, while it does not seem possible at this moment to construct a credible structural model that captures the full extent of the dynamic effects of intercontinental trade, these simulations do suggest that the broad orders of magnitude of the real wage and urbanization attributable to intercontinental trade are likely to have been high. ${ }^{22}$ And as is well-known in the finance and macroeconomics literature, reducedform models often have better predicting capabilities than attempts at structural modelling, even when it is not possible to posit causal relationships in a rigorous sense.

To be sure, one major limitation here is that the reasons why some countries failed to engage in intercontinental trade despite the large apparent advantages from doing so have not been

\footnotetext{
${ }^{20}$ One additional possibility which has not been considered here is that countries which engaged in natural resourceintensive extraction operations, namely Spain and Portugal, may have suffered Dutch disease or institutional resource curse as a consequence.

${ }^{21}$ In fact, even the methods I have used in this paper are likely to underestimate the complete beneficial effects of the intercontinental trade because with it also came new technologies, products, and ideas, which contributed to panEuropean growth and urbanization (see for instance, Nunn and Qian 2011). Since all the countries in the sample used here are in Europe, any European-wide spillover effects indirectly caused by the maintenance of empires and merchant networks by some of the countries will be, by definition, absent, since the countries treated as "controls" would have been also been affected, and hence "contaminated". Under the assumption - which certainly holds in-sample - that the empires had a positive effect on incomes, the existence of such an effect suggests that empires would have had an even stronger effect than that estimated. Additionally, the discovery of the New World may have also contributed to “opening the people's minds", hence contributing to faster scientific and technical change.

${ }^{22}$ By lumping the value of precious metals together with other types of commodities, this analysis also does not allow for the possibility of Dutch disease or institutional resource curse.
} 
explored. In some cases such as Poland, Austria, and Germany, it is possible to justify the lack of participation due to landlocked geographical conditions, but the explanation holds less power for Italy. A related point is that it is important to understand the differing degrees of participation intensity for the countries which did engage in this trade - why did France, for instance, engage much less than the "main four"? In light of the fact that these benefits seem to have been substantial, the mechanism of self-selection into engagement with, and intensity of, long-distance trade, remains as a fruitful avenue for future quantitative research. ${ }^{23}$

In sum, while Malthusian forces were certainly present, early modern Europe was not stuck at a low-income stagnation steady state (Mokyr and Voth 2009). While population pressure certainly existed, it was not everywhere sufficient to cancel the net effect of increased hours, specialization, market integration, and as time went on, the returns from intercontinental trade, which interacted with all those factors and further accrued to an increasing number of countries as time went by.

\section{References}

Allen, Robert C. (2001). The great divergence in European wages and prices from the Middle Ages to the First World War. Explorations in Economic History 38, 41 1-447.

Allen, Robert C. (2003). Progress and poverty in Early Modern Europe. Economic History Review 56, 403-43.

Allen, Robert C. (2009). The British Industrial Revolution in Global Perspective. Cambridge: Cambridge University Press.

Álvarez-Nogal, Carlos and Leandro Prados de la Escosura (2013). The rise and fall of Spain (1270-1850). The Economic History Review 66 (1): 1-37

Angeles, L. (2008). GDP per capita or real wages? Making sense of conflicting views on preindustrial Europe. Explorations in Economic History 45 (2): 147-163

Arellano, Manuel (2004). Panel Data Econometrics. Oxford University Press.

Blanning, Tim (2007). The Pursuit of Glory. Cambridge University Press.

Bond, Steve, Asli Leblebicioglu and Fabio Schiantarelli (2010). Capital accumulation and growth: a new look at the empirical evidence. Journal of Applied Econometrics 25 (7), pp. 1073-1099,

Braudel, F. (1980). Civilisation, Économie et Capitalisme. XV-XVIII Siècles. vol. 3. Le Temps du Monde. Paris: Armand Colin

${ }^{23}$ What is certain is that the intensity of per capita engagement with intercontinental trade was strongly correlated with the "maritime culture" of the country, proxied by either the size of the coast in per capita terms or the proportion of land area within $100 \mathrm{~km}$ of the seacoast (as in Gallup et al 1999). A stronger "maritime culture" would have favored the control of the seas (Blanning 2007, p. 646). This is not to say that other factors such as fiscal-military capacity did not matter as much or even more - indeed I believe they did, especially for the later periods. However, these are less credibly exogenous, and may have interacted with the former. Their analysis is beyond the scope of this paper. 
Broadberry, S., B. Campbell, A. Klein, M. Overton, and B. van Leeuwen (2011). British Economic Growth, 1270-1870: An Output -based Approach. Unpublished manuscript.

Broadberry, S., and B. Gupta (2006). The Early Modern Great Divergence: Wages, Prices and Economic Development in Europe and Asia, 1500-1 800. The Economic History Review 59(1)

Clark, Gregory (2005). The Condition of the Working Class in England, 1209-2004. Journal of Political Economy 113 (6), pp. 1307-1340

Clark, Gregory (2007). A Farewell to Alms: A Brief Economic History of the World. Princeton University Press.

Costa Leonor F., Nuno Palma and Jaime Reis (2014). The Great Escape? The Contribution of the Empire to Portugal's Economic Growth, 1500-1800. European Review of Economic History, forthcoming.

de Vries, J. d. (2008). The Industrious Revolution: Consumer Behavior and the Household Economy, 1650 to the Present. Cambridge University Press.

Findlay, Ronald and O'Rourke, Kevin H. (2007). Power and Plenty: Trade, War and the World Economy in the Second Millennium. Princeton: Princeton University Press.

Frank, Andre Gunder (1978). World Accumulation. Monthly Review Press

Gallup, John L., Jeffrey D. Sachs, and Andrew D. Mellinger (1999). Geography and economic development. International regional science review 22 (2), pp. 179-232.

Goldstone, J. A. (2002). Efflorescences and economic growth in world history: rethinking the" Rise of the West" and the Industrial Revolution. Journal of World History, 13(2), 323-389.

Hersh, Jonathan and Hans-Joachim Voth (2009). Sweet Diversity: Colonial Goods and the Rise of European Living Standards After 1492. SSRN eLibrary.

Jones, E. (1988). Growth Recurring: Economic Change in World History. Ann Harbor: The University of Michigan Press.

Lains, Pedro (1991). Foi a perda do império brasileiro um momento crucial do subdesenvolvimento português? - II’. Penélope 5, 151-63.

Malanima, Paolo (2011). The long decline of a leading economy: GDP in central and northern Italy, 1300-1913. European Review of Economic History 15 (O2), pp 169-

Marx, Karl (1990/1867). Capital: Critique of Political Economy v. 1. Penguin Classics

Myint, H. (1977), Adam Smith's Theory of International Trade in the perspective of international development. Economica 44, 231-48 
Mokyr, Joel (1985). The Industrial Revolution and the New Economic History. In Joel Mokyr (ed.) The Economics of the Industrial Revolution. Oxford: Westview Press.

Mokyr, Joel (2009). The Enlightened Economy: Britain and the Industrial Revolution, 1700-1850. Penguin.

Mokyr, Joel and Hans-Joachim Voth (2010). Understanding Growth in Europe, 1700-1870: Theory and Evidence. The Cambridge Economic History of Modern Europe. Volume 1, 1700-1870

Nickell, S. (1981). Biases in dynamic models with fixed effects. Econometrica 49, 1417-26.

Nunn, Nathan and Nancy Qian (2011). The potato's contribution to population and urbanization: evidence from a historical experiment, Quarterly Journal of Economics, 126: 593-650.

O'Brien, Patrick K. (1982). European Economic Development: The Contribution of the Periphery The Economic History Review 35(1): pp. 1-18

O'Brien, Patrick (2006) The Hanoverian state and defeat of the continental system. In: Eli Heckscher, International Trade, and Economic History (ed. Ronald Findlay, Rolf G. H. Henrikson, Hakan Lindgren, and Matts Lundahl.) The MIT Press, Boston, USA, pp. 373-408

O'Brien, P. K. and S. L. Engerman (1991). Exports and the Growth of the British Economy from the Glorious Revolution to the Peace of Amiens. In: Slavery and the Rise of the Atlantic System (ed. Barbara Solow), pp. 177-209

O'Brien, Patrick K. and Leandro Prados de la Escosura (1998a) (eds). The costs and benefits of European imperialism from the conquest of Ceuta to the treaty of Lusaka, 1974. Revista de Historia Económica (special issue) 16, pp. 29-89

Palma, Nuno and Jaime Reis (2014). Portuguese demography and economic growth, 1500-1850. Unpublished manuscript. Version presented at the University of Warwick's "Accounting for the Great Divergence” conference, Venice, May 2014

Parente, Paulo and Silva, João M. C. (2012). A cautionary note on tests of overidentifying restrictions. Economics Letters 115, 314-317.

Pedreira, Jorge (1994). Estrutura Industrial e Mercado Colonial: Portugal e Brasil (1780- 1830). Lisboa: Difel.

Pomeranz, K. (2000). The Great Divergence: China, Europe, and the Making of the Modern World Economy. Princeton University Press

Prados de la Escosura, Leandro (1988). De Império a Nación. Crecimiento y Atraso Económico en España (1780-1930). Madrid: Alianza.

Prados de la Escosura, Leandro (1993). La pérdida del imperio y sus consequencias económicas en España. In Prados de la Escosura, Leandro and Samuel Amaral (eds). La Independencia Americana: Consequencias Económicas. Madrid: Alianza Editorial, 253- 300. 
Romer, Paul (1993). Idea Gaps and Object Gaps in Economic Development. Journal of Monetary Economics, 32 (3): p. 543-73.

Solow, Robert M (1957). Technical Change and the Aggregate Production Function. Review of Economics and Statistics 39 (3): 312-320.

Stock, James H. and Yogo, Motohiro (2005). Testing for weak instruments in linear IV regression. In J.H. Stock and D.W.K. Andrews (eds), Identification and Inference for Econometric Models: Essays in Honour of Thomas J. Rothenberg. Cambridge: Cambridge University Press, ch. 5.

Thomas, R. (1968). The sugar colonies of the Old Empire: Profit or loss for Great Britain? Economic History Review 21, 30-45

Thomas, Richard P. and McCloskey, D. N. (1981). Overseas trade and empire 1700-1800. In Floud, Roderick and D. N. McCloskey(eds), The Economic History of Britain since 1700. Cambridge: Cambridge University Press, 2 vols, vol. 1, 87-102.

van Zanden, Jan Luiten and van Leeuwen, Bas (2012). Persistent but not consistent: the growth of national income in Holland, 1347-1807. Explorations in Economic History 49, 119-30.

Voth, Hans-Joachim (2001). Time and Work in England, 1750-1830. Oxford, Clarendon Press

Wallerstein, Immanuel (1974). The Capitalist World-Economy. Cambridge: Cambridge University Press.

Wallerstein, Immanuel (1980). The Modern World-System II: Mercantilism and the Consolidation of the European World-Economy, 1600-1750. New York: Academic Press.

Williams, E. (1994). Capitalism and Slavery. Chapell Hill, N.C., University of North Carolina Press. [First edition, 1944]. 


\section{Tables and figures}

\begin{tabular}{|c|c|c|c|}
\hline Dependent variable: $\log$ of the real wage & $(1)$ & $(2)$ & (3) \\
\hline Estimator & OLS & 2SLS & $\begin{array}{c}\text { Arellano-Bond } \\
\text { dynamic panel } \\
\text { GMM } \\
\end{array}$ \\
\hline Log of the land labor ratio & $\begin{array}{c}.477 * * * \\
(.066)\end{array}$ & $\begin{array}{l}444^{* * * *} \\
(.099)\end{array}$ & $\begin{array}{c}.444^{* * * *} \\
(.098)\end{array}$ \\
\hline Log of the urbanization ratio & $\begin{array}{l}.170^{* * *} \\
(.076)\end{array}$ & $\begin{array}{l}.250^{* * * *} \\
(.077)\end{array}$ & $\begin{array}{c}.25 \mathrm{O}^{* * * *} \\
(.083)\end{array}$ \\
\hline Log of the agricultural total factor productivity & $\begin{array}{l}.924 * * * \\
(.161)\end{array}$ & $\begin{array}{l}.675^{* *} \\
(.324)\end{array}$ & $\begin{array}{l}.675^{* *} \\
(.305)\end{array}$ \\
\hline Institutions dummy & $\begin{array}{l}.119 \\
(.077)\end{array}$ & $\begin{array}{c}.059 \\
(.120)\end{array}$ & $\begin{array}{l}.0593 \\
(.099)\end{array}$ \\
\hline Intercept & $\begin{array}{c}1.77 * * * \\
(.176) \\
\end{array}$ & $\begin{array}{c}2.024^{* * *} * \\
(.270) \\
\end{array}$ & $\begin{array}{c}2.024 * * * \\
(.278) \\
\end{array}$ \\
\hline $\begin{array}{c}\text { IV first stage } \\
\text { F-statistic }\end{array}$ & - & $\begin{array}{l}\text { LNAGTFP: } 23.73 \\
\text { LNURB: } 68.77\end{array}$ & 1 \\
\hline $\mathbf{R}^{2}$ & .6494 & .6270 & - \\
\hline observations & 50 & 50 & 50 \\
\hline
\end{tabular}

Table 1. The real wage equation. Standard errors are robust and small sample adjusted. In specification (3) the endogenous variables LNAGTFP and LNURB are instrumented by Allen's seven instruments and two exogenous variables (Allen 2009). All logs are natural logs. ${ }^{*}{ }^{*} *$ and ${ }^{*} * *$ denote statistical significance at the 10,5 , and $1 \%$ levels. Sources: see text.

\begin{tabular}{|c|c|c|c|}
\hline Dependent variable: Log of the urbanization ratio & $(1)$ & $(2)$ & (3) \\
\hline Estimator & OLS & 2SLS & $\begin{array}{c}\text { Arellano-Bond } \\
\text { dynamic panel } \\
\text { GMM }\end{array}$ \\
\hline Log of intercontinental trade per capita & $\begin{array}{l}123^{* * *} \\
(.060)\end{array}$ & $\begin{array}{l}.123^{* * *} \\
(.059)\end{array}$ & $\begin{array}{l}.123^{*} \\
(.070)\end{array}$ \\
\hline Log of the lagged urbanization ratio & $\begin{array}{c}.8221105^{* * * * *} \\
(.067)\end{array}$ & $\begin{array}{c}.7664851^{* * * *} \\
(.079)\end{array}$ & $\begin{array}{c}.7664851^{* * * * *} \\
(.080)\end{array}$ \\
\hline Log of the agricultural total factor productivity & $\begin{array}{l}.221 \\
(.144)\end{array}$ & $\begin{array}{l}.446^{*} \\
(.259)\end{array}$ & $\begin{array}{l}.446^{*} \\
(.241)\end{array}$ \\
\hline Institutions dummy & $\begin{array}{l}.022 \\
(.096)\end{array}$ & $\begin{array}{c}.071 \\
(.108)\end{array}$ & $\begin{array}{c}.071 \\
(.090)\end{array}$ \\
\hline Intercept & $\begin{array}{l}-.392 \\
(.181)\end{array}$ & $\begin{array}{c}-.567^{*} * \\
(.239)\end{array}$ & $\begin{array}{c}-.567^{* * *} \\
(.231)\end{array}$ \\
\hline $\begin{array}{c}\text { IV first stage } \\
\text { F-statistic }\end{array}$ & - & LNURB: 23.73 & - \\
\hline $\mathbf{R}^{2}$ & .8705 & .8653 & - \\
\hline observations & 50 & 50 & 50 \\
\hline
\end{tabular}

Table 2. The urbanization equation. Standard errors are robust and small sample adjusted. In specification (3) the endogenous variable LNAGTFP is instrumented by Allen's seven instruments and two exogenous variables (Allen 2009). All logs are natural logs. ${ }^{*}, * *$ and $* * *$ denote statistical significance at the 10,5 , and $1 \%$ levels. Sources: see text. 


\begin{tabular}{|c|c|c|c|c|c|}
\hline & England & Netherlands & Spain & France & Portugal \\
\hline \multirow{2}{*}{1500} & 0 & 0 & 0 & 0 & 1.0 \\
& $(0)$ & $(0)$ & $(0)$ & $(0)$ & $(0.3)$ \\
\hline \multirow{2}{*}{1600} & 0 & 0 & 1.1 & 0 & 2.9 \\
& $(0)$ & $(0)$ & $(0.7)$ & $(0)$ & $(0.9)$ \\
\hline \multirow{2}{*}{1700} & 2.3 & 3.7 & 2.5 & 0.3 & 5.7 \\
& $(1.0)$ & $(3.4)$ & $(1.6)$ & $(0.1)$ & $(2.0)$ \\
\hline \multirow{2}{*}{1750} & 5.4 & 7.3 & 4.3 & 1.1 & 17.0 \\
& $(2.5)$ & $(7.1)$ & $(2.8)$ & $(0.4)$ & $(7.1)$ \\
\hline \multirow{2}{*}{1800} & 18.4 & 6.1 & 6.2 & 0.9 & 22.8 \\
& $(11.7)$ & $(6.2)$ & $(3.9)$ & $(0.4)$ & $(10.8)$ \\
\hline
\end{tabular}

Table 3. Real wage increase (per cent) attributable to the effect of intercontinental trade, 15001800. (In parenthesis, increase in urbanization percentage points attributable to the effect of intercontinental trade.)

\begin{tabular}{|c|c|c|c|c|}
\hline & Poland & Italy & Germany & Austria \\
\hline \multirow{2}{*}{1500} & 0.2 & 0.1 & 0.1 & 0.1 \\
& $(0.0)$ & $(0.1)$ & $(0.0)$ & $(0.0)$ \\
\hline \multirow{2}{*}{1600} & 1.0 & 0.4 & 0.4 & 0.6 \\
& $(0.2)$ & $(0.2)$ & $(0.1)$ & $(0.1)$ \\
\hline \multirow{2}{*}{1700} & 3.4 & 1.5 & 1.5 & 2.2 \\
& $(0.8)$ & $(0.8)$ & $(0.6)$ & $(0.6)$ \\
\hline \multirow{2}{*}{1750} & 7.4 & 3.2 & 3.2 & 4.8 \\
& $(1.8)$ & $(1.8)$ & $(1.3)$ & $(1.4)$ \\
\hline \multirow{2}{*}{1800} & 12.1 & 5.4 & 5.0 & 7.7 \\
& $(3.4)$ & $(3.1)$ & $(2.2)$ & $(2.6)$ \\
\hline
\end{tabular}

Table 4. Real wage increase (per cent) attributable to the effect of (counterfactually) increasing intercontinental trade to the average level of the four main European trading nations, 1500-1800, for the countries which did not engage in intercontinental trade. (In parenthesis, percentage points increase in urbanization) 


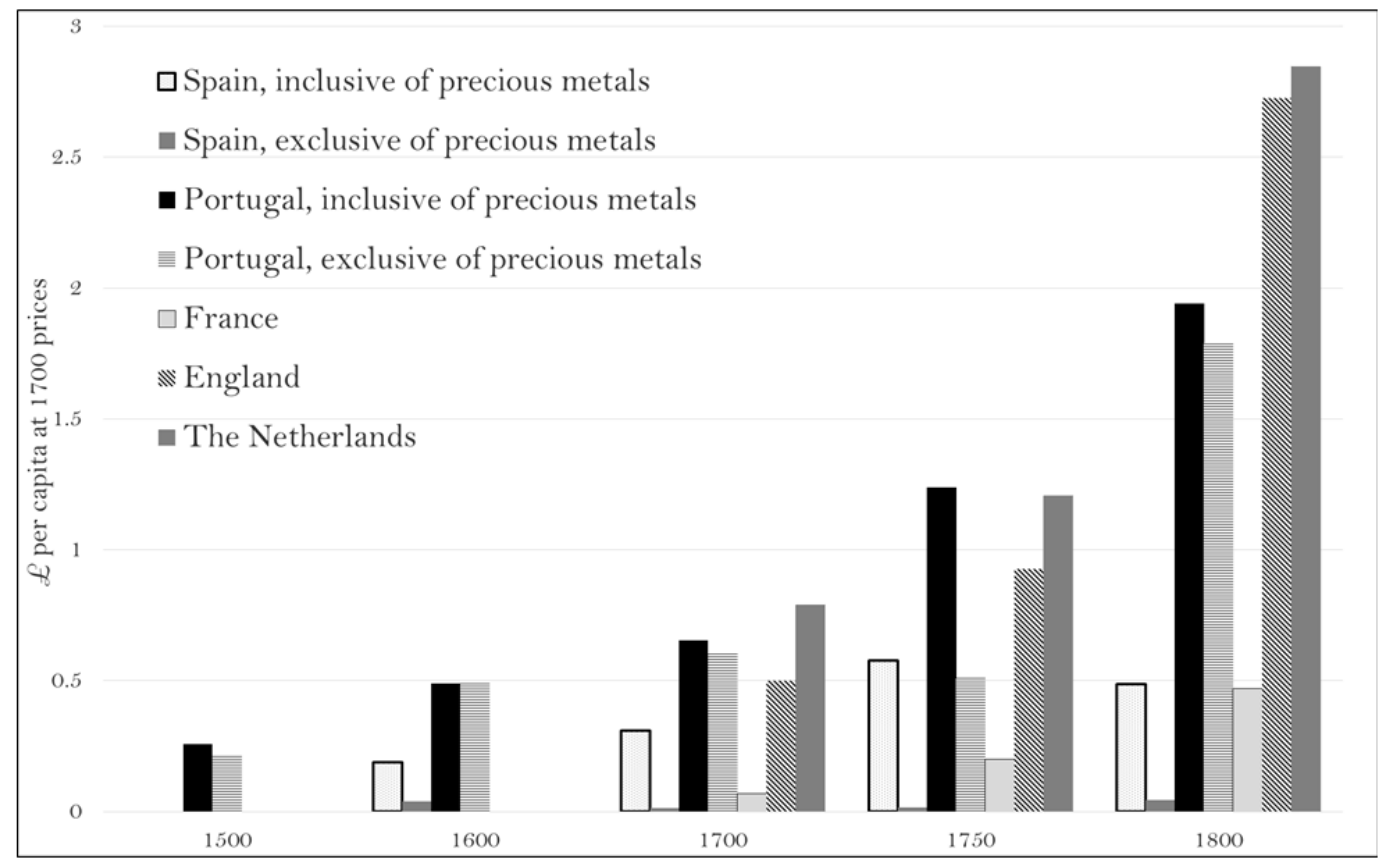

Fig 1. Intercontinental trade per capita, 1500-1800. The 1800 trade values for France correspond to 1788 and those of the Netherlands to 1780. Sources: for Portugal, Costa, Palma and Reis (2014); for France (1788), data kindly supplied by Guillaume Daudin and converted at the exchange rate of $1 / 25^{\text {th }}$ of a pound sterling per livre tournois; for the Netherlands (1780), van Zanden and van Leeuwen (2012), converted at the exchange rate of 10.5 guilders per pound sterling. For all other data, see Allen (2003).

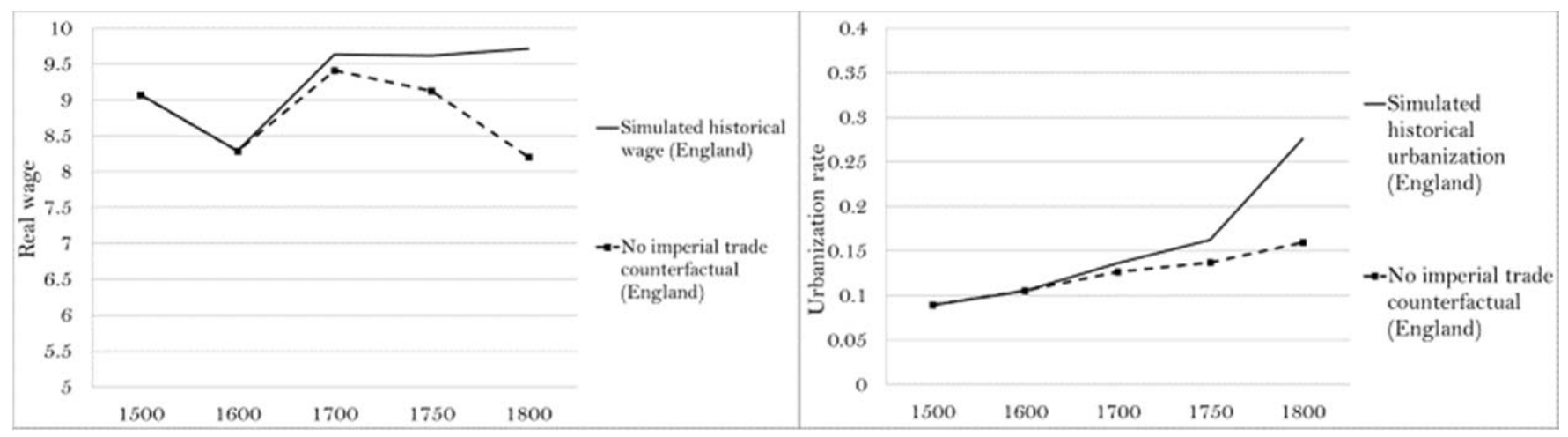

Fig 2. Simulated real wages and urbanization for England under the historical and notrade counterfactual scenarios (as in Allen 2009). 


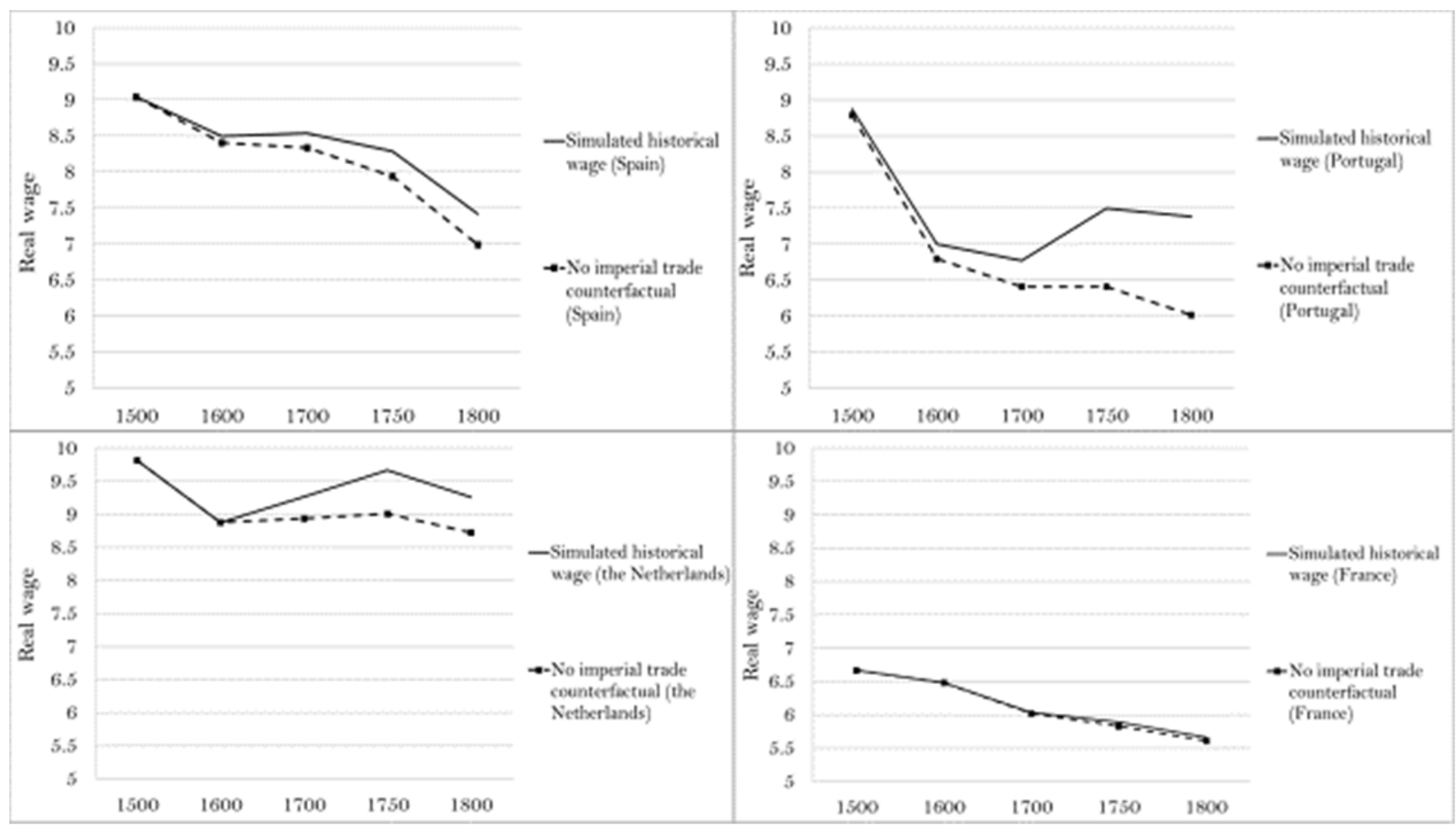

Figure 3. Simulated real wages under the historical and no-trade counterfactual scenarios (Spain, Portugal, the Netherlands, and France).

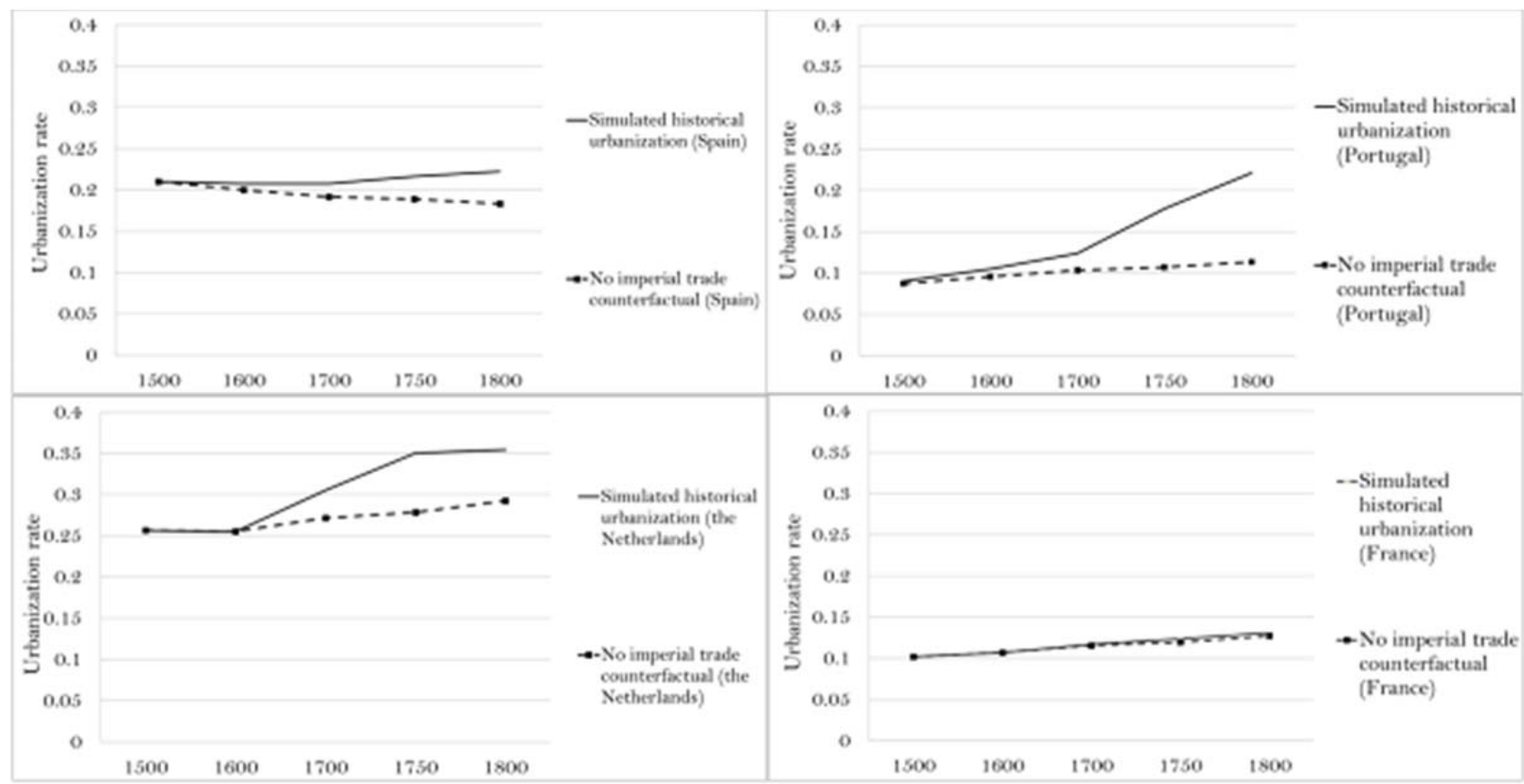

Figure 4. Simulated urbanization rates under the historical and no-trade counterfactual scenarios (Spain, Portugal, the Netherlands, and France). 


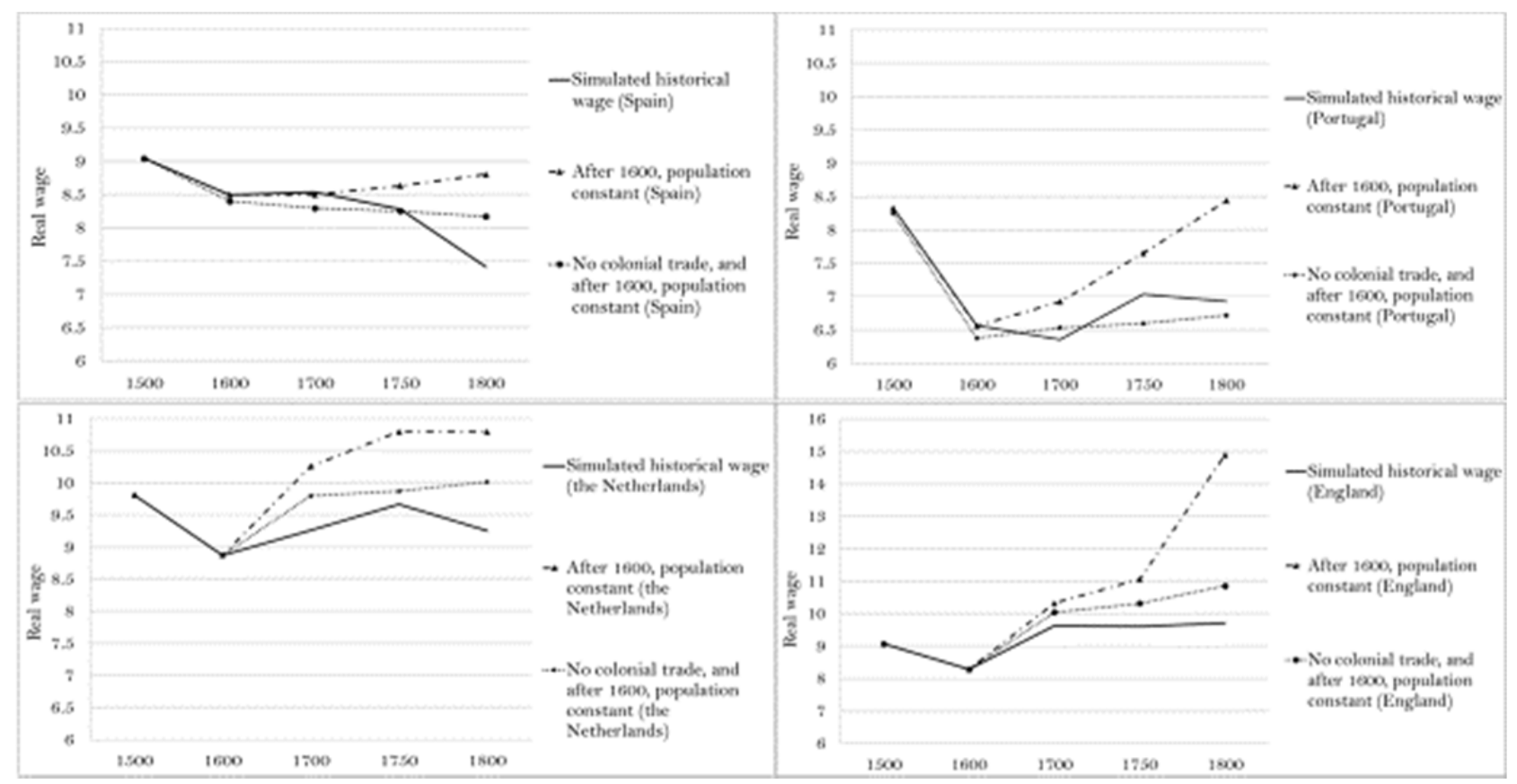

Figure 5. Simulated real wages under the historical, the "population constant after 1600", and the "no-intercontinental trade together with population constant after 1600" scenarios (Spain, Portugal, the Netherlands, and England).

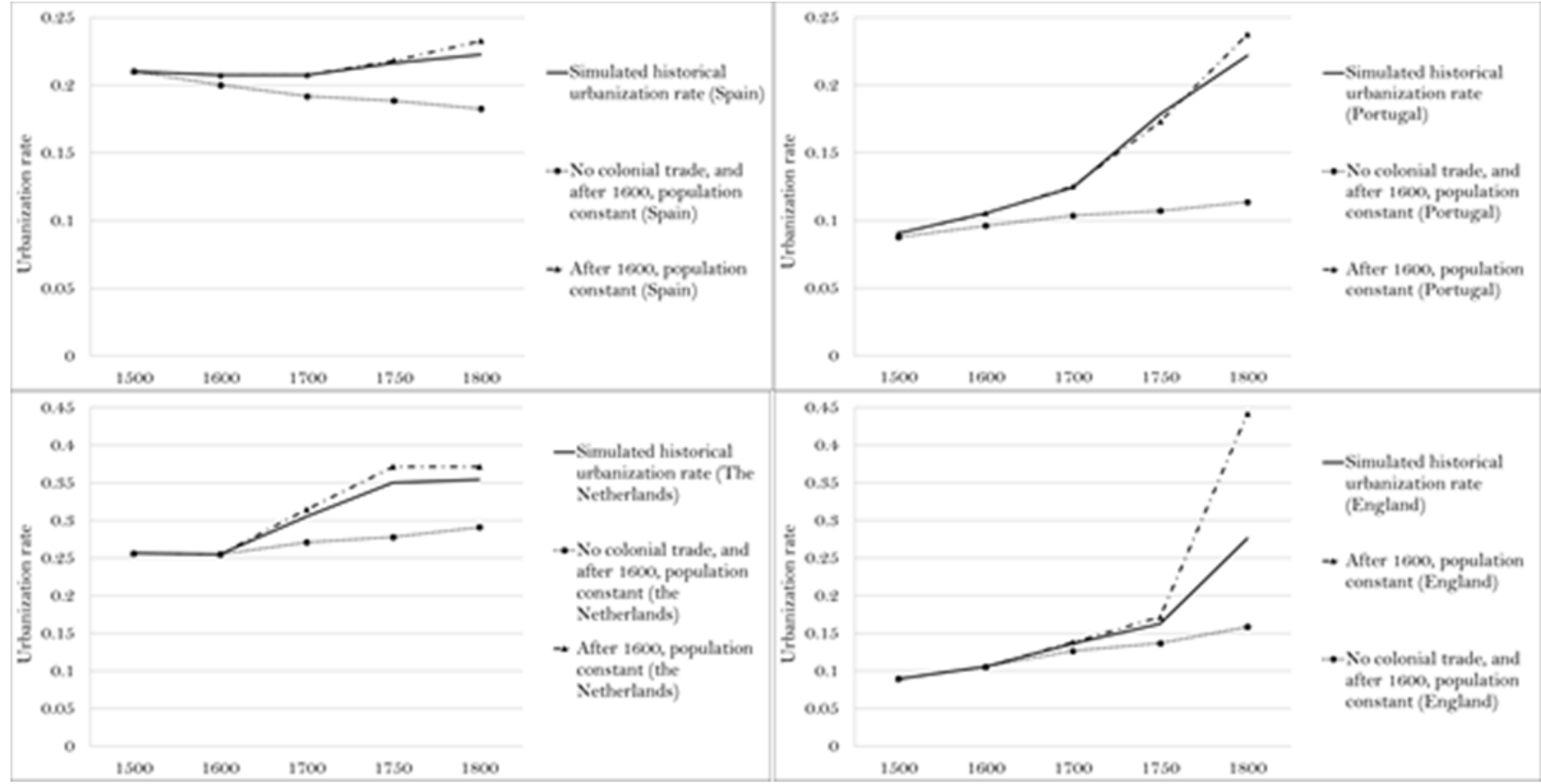

Figure 6. Simulated urbanization rates under the historical, the "population constant after 1600", and the "no-intercontinental trade together with population constant after 1600" scenarios (Spain, Portugal, the Netherlands, and England). 


\section{$\underline{\text { Appendix }}$}

In this appendix, I provide some further discussion about a technical matter related to the model's simulations. In particular, I discuss the difference between the model's prediction for the historical situtation in a given country at a given period, versus the observed values (the residual). ${ }^{24}$ It is possible to calculate the average of the absolute number of the five residuals for each country. ${ }^{25} \mathrm{I}$ now show that - with the possible exception of Belgium, due to its exceptionally high initial levels of urbanization - there are no systematic biases to the (absolute value of the average) residual for any given country (figure A 1). ${ }^{26}$ This suggests that the fit for all countries is roughtly similar and is suggestive that for any particular country the results are not being driven by unobserved specificities.

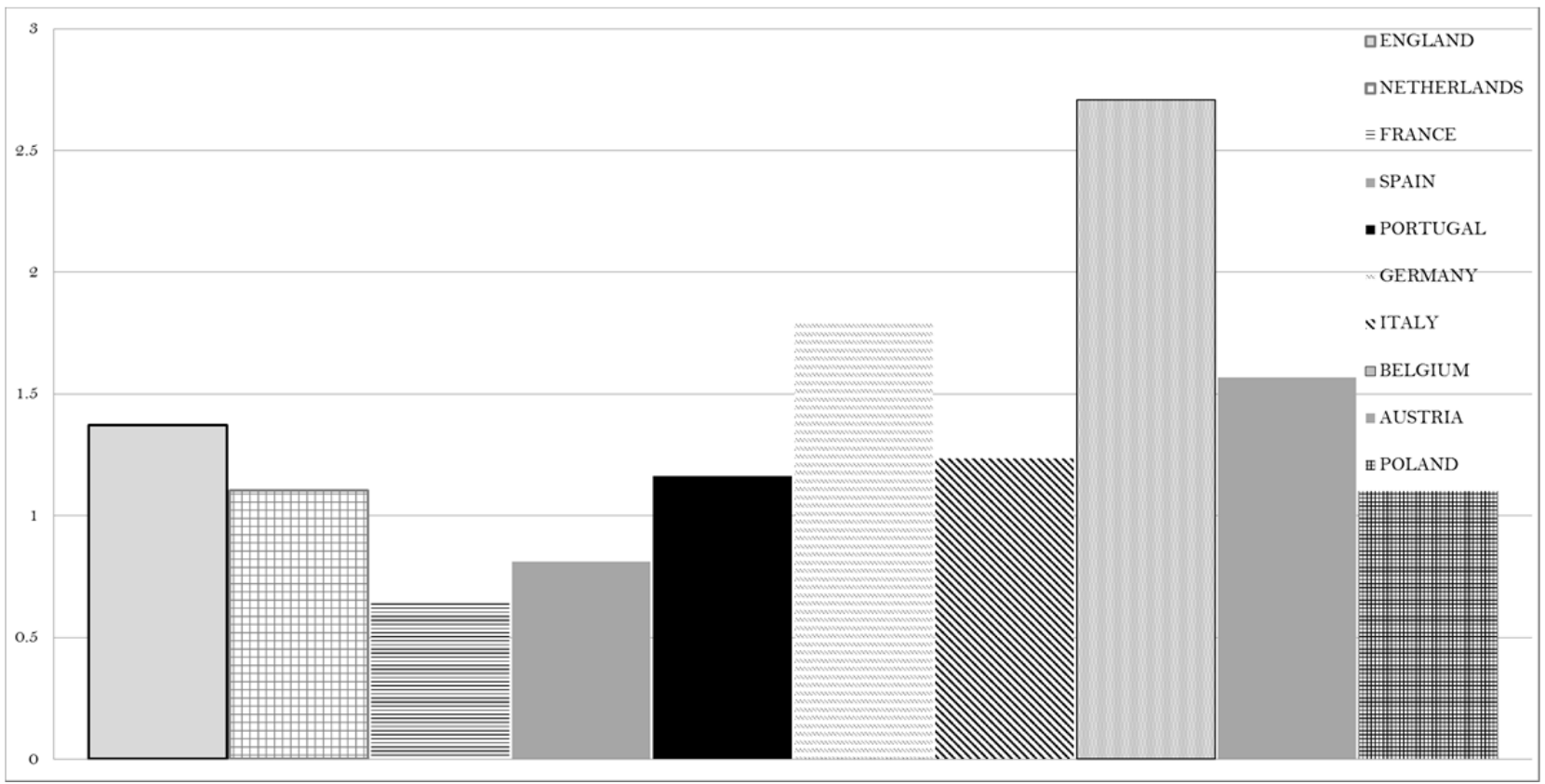

Figure A1. The average of the absolute value of the residuals (in real wage units) for all the countries in the sample.

${ }^{24}$ For each country and each benchmark year, it is possible to calculate the residual, defined as the difference between the simulated and the historical wage. (The simulated wage is simply the model's prediction for the real wage under the observed values for the exogenous variables).

${ }^{25}$ Absolute values were used for each benchmark period in the interest of values of opposing signs at different times not cancelling up.

${ }^{26}$ As with the data of figure 1 from the main text, the value of (inflation-adjusted) intercontinental trade used here for the Netherlands and France are those of 1780 (the Netherlands), and 1788 (France), respectively the last year of "normal" trade volumes; using zero instead leads to very similar results since only the terminal real wage - that of 1800 - is affected. 